YEARBOOK of ANTITRUST and REGULATORY STUDIES www.yars.wz.uw.edu.pl
Peer-reviewed scientific periodical, focusing on legal and economic issues of antitrust and regulation. Creative Commons Attribution-No Derivative Works 3.0 Poland License.

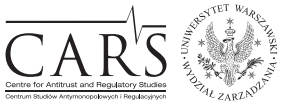

Centre for Antitrust and Regulatory Studies, University of Warsaw, Faculty of Management www.cars.wZ.uw.edu.pl

\title{
National Identity as a General Principle of EU Law and its Impact on the Obligation to Recover State Aid
}

\author{
by
}

\author{
Marek Rzotkiewicz*
}

\section{CONTENTS $^{* *}$}

\section{Introduction}

II. The notion of general principles of EU law and its development

III. General principles of EU law in the State aid area

IV. The national identity principle and its development

V. The national identity principle in the State aid area

VI. The role of the national identity principle in the EU law system

VII. The requirements for invoking the national identity principle

VIII. Conclusions

\section{Abstract}

Unlike other general principles of EU law, which derive from the CJ jurisprudence, the principle of national identity is based on a clear legal provision. Article 4(2) TEU stipulates that the Union shall respect important State functions, like the territorial integrity of the State, maintaining law and order and safeguarding national security. The list of values covered by the national principle identity is open and it is for the Member State to decide what values should be protected by its national identity, while the CJ is only empowered to determine the relevance of national identity under EU law.

This article analyses if the principle of national identity could influence the EC examination of State aid and if the EC should refrain from issuing an order to recover incompatible aid, if that aid was to be protected by the Member State's national identity.

${ }^{*}$ Legal Advisor, Phd. The author works for the Ministry of Foreign Affairs of the Republic of Poland, dealing with cases on State aid, as well as on cases concerning Energy law, including renewable energy sources. All views expressed in this text should be attributed solely to the Author and not to the Ministry of Foreign Affairs. Comments are welcome at marek_rzotkiewicz@yahoo.com.

** Article received: 5 April 2016; accepted: 23 May 2016. 
There has not yet been a single judgment by the $\mathrm{CJ}$ on that issue and the question stays open. The analysis also focuses on the division of competences between Member States and EU institutions in carrying out that analysis, as well as on the requirements for that analysis, including the scope of an examination carried out by EU institutions.

\section{Resumé}

Contrairement aux autres principes généraux du droit de l'Union européenne, qui découlent de la jurisprudence de la Cour de justice de l'Union européenne, le principe de l'identité nationale est basé sur une disposition légale claire. L'article 4(2) du Traité sur l'Union européenne prévoit que l'Union doit respecter les fonctions essentielles de l'État, comme l'intégrité territoriale de l'État, le maintien de l'ordre public et la sauvegarde de la sécurité nationale. La liste des valeurs couvertes par le principe de l'identité nationale est ouverte et c'est aux États membres de décider quelles valeurs doivent être protégées par son identité nationale, tandis que la Cour de justice de l'Union européenne est uniquement compétente à déterminer la pertinence de l'identité nationale en vertu du droit de l'Union européenne.

Cet article analyse si le principe de l'identité nationale pourrait influencer l'examen d'aide d'État par la Commission européenne et si la Commission européenne devrait s'abstenir d'ordonner la récupération de l'aide incompatible, et à la fin si cette aide devait être protégée par l'identité nationale de l'État membre. Vu que jusqu'au présent il n'y avait pas un seul jugement de la Cour de justice de l'Union européenne concernant ce problème, la question reste ouverte. Lanalyse entrepris dans cet article se focalise également sur la répartition des compétences entre les États membres et les institutions de l'Union européenne dans le traitement de ce problème, ainsi que sur les exigences pour l'analyse entrepris par l'autorité compétente, y compris sur la portée d'un examen effectué par les institutions de l'Union européenne.

Key words: general principle of EU law; national identity; recovery; state aid.

JEL: K21; K40

\section{Introduction}

Where the European Commission (hereafter, EC) finds aid incompatible with the Internal Market (incompatible aid), it shall decide that the Member State concerned shall take all necessary measures to recover the aid from the beneficiary ${ }^{1}$ (recovery order). Once the EC finds the aid to be incompatible, it

1 Article 16(1) first sentence of Council Regulation (EU) No. 2015/1589 of 13 July 2015, laying down detailed rules for the application of Article 108 of the Treaty on the Functioning of the European Union (OJ L 248/9) (hereafter, Procedural Regulation). 
is bound to issue a recovery order ${ }^{2}$, unless this would be contrary to a general principle of EU law ${ }^{3}$. In such a case, the EC should restrict itself to finding that the aid is incompatible (issuing a 'negative decision') and refrain from ordering its recovery. An example of such a solution can be found in the case of France Télécom ${ }^{4}$, or in the Italian scheme on the municipal real estate tax exemption covering properties used by non-commercial entities for specific purposes $^{5}$. Those and other cases posted on the EC website provide evidence that the issue of a negative decision does not have to mean that a Member State has been ordered to recover the aid 6 .

Although this paper is devoted to the principle of national identity, it is necessary to first clarify the very idea of general principles of EU law. This can greatly improve the understanding of the notion of the national identity principle, and its place among other general principles of EU law. It can also help clarify the differences between national identity and other EU principles with regard to the recovery of State aid. In light of the above considerations, and after this introduction (Point I), the paper will first refer to the notion and development of general principles of EU law overall (Point II), followed by its evolution in the area of State aid law (Point III). Next, the paper will deal with the national identity principle in general (Point IV), and in the area of State aid law in particular (Point V). The role of the national identity principle in the system of EU law will be discussed next (Point VI), followed by the requirements for its use (Point VII). The paper will close with conclusions (Point VIII). Still, although it is necessary to make references in this paper to the notion of general principles of EU law, any such references are made solely in order to make the national identity principle more understandable. For this reason, the general principles of EU law are not examined in this paper in an exhaustive manner considering that they deserve a separate and detailed examination (Tridimas, 2006).

This paper will therefore provide an attempt to answer certain questions concerning the meaning and boundaries of the national identity principle, as well as its impact on the issuance by the EC of recovery orders. Those questions relate to the idea of who has the right to find that a certain value is protected by this principle - a Member State or an EU institution? If that

2 It is then possible to make an application against the EC to the Court of Justice (hereafter, CJ) under Article 263 TFEU and make a claim that on the basis of objective evidence the EC should have issued a recovery order, and by not doing so it has breached EU law.

3 Article 16(1) second sentence of the Procedural Regulation.

${ }^{4}$ Decision C (2004) 3060, para. 261-262.

5 Decision C (2012) 9461, para. 181.

${ }^{6}$ Until 20 May 2016 the EC issued 144 negative decisions, in which it found the aid to be incompatible, but refrained from ordering its recovery (see: http://ec.europa.eu/competition/ elojade/isef/index.cfm?fuseaction=dsp_result). 
right lies with an EU institution, should the latter raise the issue of national identity on its own or only after a Member State claimed a breach of that principle and the necessity of its protection? Alternatively, if that right lies with a Member State, when should it make such a reference? These and many other, much more detailed questions deserve to be addressed in this context. It is not, however, the aim of this paper to seek an answer to all of the above questions but rather to examine the notion of national identity and its impact on the obligation to recover State aid. However, as national identity is just one of the many general principles of EU law, this paper examines national identity from the perspective of general principles of EU law.

\section{The notion of general principles of EU law and its development}

It is noteworthy that although the Procedural Regulation refers to the notion of general principles of Union law, it does not clarify the meaning of that concept. This is all the more striking, as the very idea of general principles of Union law is a vague concept - not defined in any laws or regulations ${ }^{7}$. It is the result of the jurisprudence of the Court of Justice (hereafter, CJ) (Cieśliński, 2003, p. 11; Mik, 2000, p. 486), which has developed a relatively autonomous meaning of that notion on a case by case basis. The CJ (formerly referred to as European Court of Justice, ECJ) has on many occasions referred to general principles of EU law; one may even find judgments and opinions on the concept of national identity ${ }^{8}$, however scarce they may be. The CJ has referred to the principles of: non-discrimination ${ }^{9}$, proportionality ${ }^{10}$, direct effect ${ }^{11}$, and right to defence ${ }^{12}$. The $\mathrm{CJ}$ has also taken a closer look at fundamental human rights ${ }^{13}$ and at the constitutional traditions common to

7 The term 'regulation' in this paper is used with regard to soft law.

8 C-473/93 Commission v. Luxemburg, ECLI:EU:C:1996:263, para. 36; opinion AG Maduro in Michaniki, C-213/07, ECLI:EU:C:2008:544, para. 31; C-208/09 Sayn-Wittgenstein, ECLI:EU:C:2010:806, para. 83 and 92; C-391/09 Runevič-Vardyn, ECLI:EU:C:2011:291, para. 86; C-51/08 Commission v. Luxemburg, ECLI:EU:C:2011:336, para. 124; C-393/10 O'Brien, ECLI:EU:C:2012:110, para. 49; C-202/11 Las, ECLI:EU:C:2013:239, para. 26; C-58/13 and C-59/13 Torresi, ECLI:EU:C:2014:2088, para. 56-59.

9 8/55 Fédération Charbonière Belgique v. High Authority, ECLI:EU:C:1956:11.

10 14/59 Pont-à-Mousson v. High Authority, ECLI:EU:C:1959:31.

11 6/64 Costa v. E.N.E.L., ECLI:EU:C:1964:66.

12 32/62 Alvis v. Council, ECLI:EU:C:1963:15.

13 29/69 Erich Stauder v. City of Ulm, ECLI:EU:C:1969:57. 
EU Member States ${ }^{14}$. Accordingly, the CJ has stated that it cannot uphold measures incompatible with fundamental rights recognized and protected by the constitutions of those States. Finally, the CJ has recognized the European Convention of Human Rights as binding on Member States ${ }^{15}$, as well as the Charter of Fundamental Rights, which may have direct effect on the national legal systems of Member States (Fontanelli, 2011).

Those cases derive from a wide range of economic sectors, including the coal and steel industry ${ }^{16}$, distribution of electricity ${ }^{17}$ or agriculture ${ }^{18}$. They also stem from various legal areas such as: staff cases ${ }^{19}$, competition ${ }^{20}$ and free movement of workers ${ }^{21}$. In all these types of cases, the CJ has frequently referred to general principles of law and confirmed its attachment to them.

\section{General principles of EU law in the State aid area}

The aforementioned interest of the $\mathrm{CJ}$ in general principles of law is also evident in State aid cases. In this area, EU courts have frequently referred to the right to defence ${ }^{22}$, the right to ownership ${ }^{23}$, legitimate expectations ${ }^{24}$, ne bis in idem $^{25}$, the right to good administration ${ }^{26}$, the res judicata ${ }^{27}$, as well as to other principles. The number of those references does not, however, mean that general principles of EU law play a particularly prominent role in the State aid area.

14 4/73 Nold, Kohlen and Baustoffgrosshandlung v. Ruhrkohle Aktiengesellschaft, ECLI:EU:C:1974:51.

15 36/75 Rutili v. Ministre de lIntérieur, ECLI:EU:C:1975:137.

16 14/59 Pont-à-Mousson v. High Authority; 8/55 Fédération Charbonière Belgique v. High Authority.

17 6/64 Flaminio Costa v. E.N.E.L..

18 11/70 Internationale Handelsgesellschaft mbH/Einfuhr und Vorratsstelle für Getreide und Futtermittel, ECLI:EU:C:1970:114.

19 32/62 Alvis v. Council, ECLI:EU:C:1963:15.

20 T-30/91 Solvay S.A, ECLI:EU:T:1995:115, according to which 'Respect for the rights of the defence in all proceedings in which sanctions may be imposed is a fundamental principle of Community law which must be respected in all circumstances, even if the proceedings in question are administrative proceedings'.

21 152/73 Giovanni Maria Sotgiu v. Deutsche Bundespost, ECLI:EU:C:1974:13.

22 T-309/04, T-317/04, T-329/04 and T-336/04TV2/Denmark et al., ECLI:EU:T:2008:457.

23 T-228/99 and T-233/99 Westdeutsche Landesbank Girozentrale et al., ECLI:EU:T:2006:405.

24 T-62/08 ThyssenKrupp Acciai Speciali Terni SpA, ECLI:EU:T:2010:268.

25 T-68/03 Olympiaki Aeroporia Ypiresies AE, ECLI:EU:T:2007:253.

26 T-25/04 González y Díez SA, ECLI:EU:T:2007:257.

27 C-119/05 Ministero dell'Industria, del Commercio e dell'Artigianato/Lucchini SpA, ECLI:EU:C:2007:434. 
Practically, the proportionality principle has no significance as the CJ consistently states that the recovery of unlawful aid is the logical consequence of finding that a given State measure is unlawful ${ }^{28}$. Consequently, the recovery of unlawfully granted State aid, in order to establishing pre-existing market conditions, cannot in principle be regarded as disproportionate to the objectives of the Treaty ${ }^{29}$. Similarly, the ne bis in idem principle has no bearing following the view that the recovery is not a penalty (Brandtner, 2013). When it comes to other principles, the right to defence cannot be used by a beneficiary as the latter is not a party to the administrative proceedings before the EC - this principle can only be used by the Member States ${ }^{30}$.

Among the many principles invoked by the parties to the disputes before EU courts in the State aid area, the following principles have the greatest chances for success: legitimate expectations ${ }^{31}$, legal certainty ${ }^{32}$, and the right to defence ${ }^{33}$ when used by a Member State. Nonetheless, it is not an easy task to use them successfully (Giraud, 2008).

\section{The national identity principle and its development}

Unlike other general principles of EU law, which derive from the CJ jurisprudence (Cieśliński, 2003, p. 11; Mik, 2000, p. 486), the national identity principle is based on a clear legal provision. It was introduced into EU law in 1992 by the Maastricht Treaty, Article F (1): 'The Union shall respect the national identities of its Member States, whose systems of government are founded on the principles of democracy'. The clause was later revised by the Amsterdam Treaty of 1997 which removed the second part of the sentence and left its first part stating: 'The Union shall respect the national identities of its Member States'. The provision in question was finally given its current

28 Although the CJ refers to unlawful aid, it is necessary to comment that the decisive factor for issuing the recovery order is not the unlawfulness of the aid but its incompatibility with the Internal Market. Even if the EC finds the aid to be unlawful (granted without EC approval), it still has to examine its compatibility with the Internal Market in order to order its recovery.

29 C-142/87 Tubemeuse v. Commission, ECLI:EU:C:1990:125, para. 66; T-459/93 Siemens, ECLI:EU:T:1995:100, para. 96; C-169/95 Spain v. Commission, ECLI:EU:C:1997:10, para. 47; T-312/97, T-313/97, T-315/97, T-600/97 to 607/97, T-1/98, T-3/98 to T-6/98 and T-23/98, Alzetta Mauro et al., ECLI:EU:T:2000:151, para. 169.

30 T-613/97 Union française de l'express (Ufex), DHL International, Federal express international and CRIE, ECLI:EU:T:2000:304, para. 85-86.

31 Decision C (2004) 3060, para. 263.

32 T-308/00 Salzgitter, ECLI:EU:T:2004:199, para. 166.

33 Decision C (2004) 3060, para. 261-262. 
reading by the Lisbon Treaty. The latter not only renumbered the articles of the TEU 34 but also gave Article 4(2) TEU its current shape: 'The Union shall respect the equality of Member States before the Treaties as well as their national identities, inherent in their fundamental structures, political and constitutional, inclusive of regional and local self-government. It shall respect their essential State functions, including ensuring the territorial integrity of the State, maintaining law and order and safeguarding national security. In particular, national security remains the sole responsibility of each Member State'.

It is discernible from the above reading of Article 4(2) TEU that the principle of national identity stems from fundamental structures of Member States and their constitutions, including their regional and local selfgovernments. It appears that the range of values which might seek protection under this principle is not limited in scope, and that it is for Member States to decide which values are sufficiently important for a given State that they must be protected by the national identity principle. Hence, for instance, while Austria claimed in Sayn-Wittgenstein that the removal of the title of nobility and nobiliary particle forming part of surnames is necessary for the protection of its national identity, it is possible that in another Member State, for example in the United Kingdom, the exact opposite (not the removal but in fact maintaining such title or particle) would be covered by that State's national identity.

A Member State's decision on matters concerning EU law does not generally ${ }^{35}$ bind EU institutions, although EU courts have the jurisdiction to adjudicate any disputes deriving from it. As a result, EU courts can state that although a certain value put forward by a Member State does in fact deserve protection under the national identity principle, in the case before the Court, the Member State concerned cannot rely on that principle due to, for instance, lack of proportionality of the national measures ${ }^{36}$.

Even though the national identity principle has been part of EU law since the Maastricht Treaty, and both parties to disputes before EU courts as well as Advocates General have on certain occasions referred to that principle, EU courts have extremely rarely recognized the duty of the EU to respect this principle. Cases in which the CJ has found this principle worthy of judicial protection are even scarcer. To the Author's knowledge, the CJ has expressly referred to this principle only once before the Treaty of Lisbon entered into force. The CJ stated that although the national identity principle cannot justify the exclusion of nationals of other Member States from all the posts in an area

\footnotetext{
34 Article F TEU became its Article 4.

35 Unless EU law provides otherwise.

36 Opinion AG Maduro, Michaniki, C-213/07, ECLI:EU:C:2008:544.
} 
such as education, this is not the case with regard to posts involving direct or indirect participation in the exercise of powers conferred by public law and duties designed to safeguard the general interests of the State or of other public authorities ${ }^{37}$.

It must also be noted that although the CJ considered, on some occasions, this principle as a means of adjudication of cases before it, and it has, in fact, based its judgments on this principle, it nevertheless strayed from making any reference to $\mathrm{it}^{38}$. In those cases, the $\mathrm{CJ}$ obliquely referred to national constitutions.

The CJ's reluctance to employ the national identity principle in its considerations seems to have changed after the Treaty of Lisbon came into force. Since that date, the CJ referred to the national identity principle on six occasions ${ }^{39}$ - as compared to only one such example before ${ }^{40}$. However, three of those new cases were unsuccessful for the parties attempting to invoke the national identity principle. In Commission v. Luxemburg, the CJ rejected arguments based on this principle because of the disproportionality of the national measures in question ${ }^{41}$. In O'Brien, although the Latvian Government in its written submissions invoked the national identity principle, the $\mathrm{CJ}$ found that remuneration of part-time judges on a daily-fee-paid basis could not have any effect on national identity. According to the $\mathrm{CJ}$, this manner of establishing their pay level merely aims to extend to them the scope of the principle of equal treatment and to protect them against discrimination as compared with full-time judges ${ }^{42}$. In the third of the unsuccessful cases, Torresi, the CJ held that Article 3 of Directive 98/543 concerns solely the right of establishing legal practice in a Member State in order to practice the profession of a lawyer under the professional title obtained in the home Member State. That provision regulates neither access to the profession of lawyer nor the practice of that profession under the professional title issued in the host Member State, and it therefore cannot affect the Member State's national identity ${ }^{44}$.

37 C-473/93 Commission v. Luxemburg, para. 36.

38 C-213/07 Michaniki, EU:C:2008:731; C-36/02 Omega, ECLI:EU:C:2004:614.

39 C-208/09 Sayn-Wittgenstein, para. 83 and 92; C-391/09 Runevič-Vardyn, para. 86; C-51/08 Commission v. Luxemburg, para. 124; C-393/10 O’Brien, para. 49; C-202/11 Las, para. 26; C-58/13 and C-59/1 Torresi, para. 56-59.

${ }^{40}$ See the footnote no 37.

41 C-473/93 Commission v. Luxemburg, para. 124.

42 C-393/10 O'Brien, para. 49.

43 Directive 98/5/EC of the European Parliament and of the Council of 16 February 1998 to facilitate practice of the profession of lawyer on a permanent basis in a Member State other than that in which the qualification was obtained (OJ L 77/36).

44 C-58/13 and C-59/13 Torresi, ECLI:EU:C:2014:2088, para. 56-59. 
On the other hand, of those cases where parties managed to successfully invoke the national identity principle, special regard (also from the Polish perspective ${ }^{45}$ ) should be given to Runevič-Vardyn. The CJ stated therein that the EU must respect the national identity of its Member States which includes the protection of their official national languages ${ }^{46}$. Therefore, according to the $\mathrm{CJ}$, national rules that provide that a person's surnames and forenames may be entered on civil status certificates of a given State only in a form which complies with the rules governing the spelling of its official national language relate to a situation which does not come within the scope of Council Directive 2000/43/EC of 29 June 2000 implementing the principle of equal treatment between persons, irrespective of their racial or ethnic origins ${ }^{47}$. That reasoning was later reiterated in $\mathrm{Las}^{48}$ where the CJ referred to Runevič-Vardyn stating that the EU must respect the national identity of its Member States, which includes the protection of their official language or languages. In the third successful case after the Lisbon Treaty, albeit chronologically the first, (SaynWittgenstein), the CJ accepted Austria's claim that it had sought to protect its constitutional republican identity. The $\mathrm{CJ}$ agreed that the law on the abolition of nobility constitutes a fundamental decision in favour of formal equality of treatment of all citizens before the law ${ }^{49}$.

In order to complete the above discussion, it is also worth mentioning the recently adjudged case Poland v. European Parliament and Council. Poland sought therein the annulment of Directive 2014/40/EU concerning the manufacture, presentation and sale of tobacco and related products (menthol cigarettes). Although Poland has not invoked the national identity principle, but reference to it was made by the Advocate General. The AG stated that the CJ's considerations must always be applied considering the general interest of the EU, while the situation of any particular Member State taken individually is, as a rule, not relevant. Any exceptions may be applied only where the action envisaged by EU institutions affects the national identity of a given Member State or its fundamental interests. However, in the opinion of the $\mathrm{AG}$, it would be startling if the problems relating to the manufacture, sale and consumption of menthol cigarettes were to be regarded seriously as a matter of national interest or national identity ${ }^{50}$. Although the $\mathrm{CJ}$ did not refer at

45 The Author of this text lives and works in Poland.

46 C-391/09 Runevič-Vardyn, ECLI: EU:C:2011:291, para. 86.

47 Council Directive 2000/43/EC of 29 June 2000 implementing the principle of equal treatment between persons irrespective of racial or ethnic origin (OJ L 180/22).

48 C-202/11 Las, para. 26.

49 C-208/09 Sayn-Wittgenstein, ECLI:EU:C:2010:806.

50 Opinion AG Kokot, C-358/14 Poland v. European Parliament and Council, ECLI:EU:C:2015:848, para. 166. 
all in its judgment to this principle ${ }^{51}$, the AG opinion may be a valuable indication as to how to understand this principle (or, more precisely, how not to understand it).

It is striking that the number of cases where the $\mathrm{CJ}$ has referred to the principle of national identity has risen only after the Treaty of Lisbon came into force. It is thus justifiable to ask why the $\mathrm{CJ}$ has previously been reluctant to consider this issue. The argument has been put forward, as a possible answer to this question, that the $\mathrm{CJ}$ did not have jurisdiction to adjudicate claims based on the national identity principle before the entry into force of the Treaty of Lisbon. According to this line of argumentation, the preLisbon version of Article 46 TEU exhaustively listed matters that fell under the jurisdiction of the $\mathrm{CJ}$ - and national identity was not one of them - hence, the CJ could not hear such cases (Besselink, 2012).

This approach is unconvincing, however. First of all, one must point out that in Commission v. Luxemburg, the CJ clearly and unequivocally based its judgment on the national identity principle ${ }^{52}$. The $\mathrm{CJ}$ found therein that it had jurisdiction to adjudicate national identity-based claims, regardless of the lack of any such references in the then applicable Article 46 TEU. Should, however, anyone still wish to defend the argument that the CJ did not have jurisdiction to adjudicate on national identity issues before the Lisbon Treaty entered into force, then he/she must also be ready to defend all CJ judgments based on the fundamental rights clause issued during that time period. $\mathrm{He} / \mathrm{she}$ must then be prepared to demonstrate that all those judgments have not been issued ultra vires. The national identity clause, included in Article 4(2) TEU and the requirement that the EU should respect fundamental rights embedded in Article 6(3) TEU, bear a strong resemblance. Also, the fundamental rights clause, similarly to the national identity clause, was originally excluded from the then applicable Article L, which preceded Article 46 TEU. Nonetheless, it had not stopped the CJ from adjudicating on fundamental rights (Cloots, 2015, p. 66).

\section{The national identity principle in the State aid area}

This paper aims to examine the impact the national identity principle can have on the obligation to recover State aid, and specifically whether it can stop the EC from ordering a Member State to recover the aid. However, according to the Author's best knowledge, there has never been a case yet

\footnotetext{
51 C-358/14 Poland v. European Parliament and Council, ECLI:EU:C:2016:323.

52 C-473/93 Commission v. Luxemburg, ECLI:EU:C:1996:263, para. 36.
} 
where the EC, or EU courts, have actually confirmed such a possibility. Although the $\mathrm{CJ}$ has referred on some occasions to national identity ${ }^{53}$, it has not dealt with such a case specifically in the State aid area so far. On the other hand, neither the courts nor the EC have actually ruled out such a possibility. Moreover, as mentioned before, the CJ based its Commission v. Luxemburg judgment on the principle of national identity ${ }^{54}$ regardless of the lack of any references to national identity in the then applicable version of Article 46 TEU. Lastly, the very notion of general principles of EU law is the result of the CJ jurisprudence, not of EU legislation.

It can thus be argued that there is a possibility to successfully invoke the national identity principle in State aid cases. Still, this does not mean that such cases would be numerous. Current CJ jurisprudence suggests that cases where the EC should refrain from ordering the recovery of aid due to its incompatibility with the national identity principle would, in fact, remain an exception. They would need to meet strict requirements, especially because applying the national identity principle in order to stop the EC from ordering a Member State to recover the aid would mean giving precedence to national interests over the interests of the EU. This is particularly noteworthy since according to the $\mathrm{CJ}$ jurisprudence, EU interest in restoring pre-existing market conditions by recovering incompatible aid must normally, if not always, take precedence over the interest of avoiding enforcement of the obligation to repay it ${ }^{55}$.

\section{The role of the national identity principle in the EU law system}

According to well-established jurisprudence of EU courts, EU law has absolute primacy over national legislation regardless of its nature ${ }^{56}$ - this means absolute supremacy also over national constitutions ${ }^{57}$. However, this conclusion differs from positions taken by national constitutional or supreme courts $^{58}$ including, for example, those frequently taken by German ${ }^{59}$ or Polish ${ }^{60}$

53 See the footnote no. 8.

54 C-473/93 Commission v. Luxemburg, para. 36.

55 T-198/01 R Technische Glaswerke Ilmenau GmbH, para. 114.

56 6/64 Flaminio Costa v. E.N.E.L.; 106/77 Simmenthal, ECLI:EU:C:1978:49, para. 17.

57 11/70 Internationale Handelsgesellschaft $m b H$ v. Einfuhr und Vorratsstelle für Getreide und Futtermittel, ECLI:EU:C:1970:114.

58 Not all Member States of the EU have specialized constitutional tribunals, and in some Member States this role is assigned to their supreme courts.

59 Judgment BVerfGE 37; judgment BVerfGE 73; judgment BVerfGE 89.

${ }^{60}$ Judgment K 18/04; judgment K 32/09; judgment K 45/09. 
constitutional courts (later noted and discussed by European scholars (Cloots, 2015, 5). Those constitutional or supreme courts do not, as it must be stressed, reject the primacy of EU law over national laws of EU Member States, but they stress that the primacy of EU law does not apply to national constitutions. Effectively therefore, they disagree with the CJ over the character and scope of that primacy and stress that it is not absolute, as the CJ would like, but rather relative and limited in scope.

The question whether such conflicting positions can be reconciled depends on what character one attributes to the EU law system. If one believes that its character is hierarchical, then it is justifiable to say that the positions taken by national constitutional or supreme courts have no legal basis. One must also remember that the supreme and final judge, which will hear and adjudicate such disputes, sits in Luxemburg and he/she will be adjudicating cases according to EU law - a law that favours the view on its own absolute primacy. That is, that the system of EU law is of hierarchical character.

If, on the other hand, one believes that the EU law system, which is composed of the law made by EU institutions and by the law made by EU Member States, is not hierarchical but rather multi-centric (Lętowska, 2008a; Łętowska, 2008b), or composite (Thym, 2009; Von Bogdandy and Schill, 2011), then it is possible that those differing positions can be abridged. It would be not necessary in such case for the sake of the effectiveness of EU law to grant EU law absolute primacy over national laws of EU Member States. 'The characteristic feature of a composite structure (Verbund) is the intertwining of cooperation and hierarchy as ordering paradigms for the conduct of actors in the European legal space. The concept of composite constitutionalism transcends traditional and somewhat simplistic ideas about the relationship between different constitutional orders, especially those that operate with simple supra- and subordination, where one legal order necessarily trumps another. Instead, the Verbund concept highlights both the autonomy of the actors at EU and national levels, and their mutual dependence in their quest to achieve common aims, thus requiring loyal cooperation and the submission to a uniform legal regime' (Von Bogdandy and Schill, 2011).

This view gains support from the national identity clause, as well as from the CJ jurisprudence where the latter starts to notice the need to protect the national identities of EU Member States. Even though the CJ has only in extremely exceptional cases found that it would be justifiable for national constitutions to take precedence over EU law ${ }^{61}$, and only if strict requirements were to be met, the very acceptance of that notion suggests that the primacy of EU law has lost its absolute character.

61 Opinion AG Maduro, C-213/07 Michaniki, para. 31; C-208/09 Sayn-Wittgenstein, para. 83 and 92. 


\section{The requirements for invoking the national identity principle}

The national identity principle is one of the general principles of EU law. It could thus be argued, similarly to other general principles (Jaros and Ritter, 2004, p. 1; Sinnaeve, 2010, p. 642), that EU institutions should examine (even ex officio ${ }^{62}$ ) whether in a case at hand the national identity of a Member State is endangered. As a result, it would be for EU institutions not only to conduct such an examination (procedural aspect), but also to decide on what deserves protection under that principle (substantive aspect). Support for the above approach could derive from the fact that Article 4(2) TEU, like other provisions of EU law, is subject to the interpretation and control of the CJ. By contrast, it could also be argued (frequently so, for example by the German Federal Constitutional Court ${ }^{63}$ and by the Polish Constitutional Tribunal ${ }^{64}$ ) that it is for the national constitutional courts to decide these issues and that the compliance of actions taken by EU institutions with the national identity clause cannot be effectively controlled by EU institutions.

An opinion is also expressed that neither of the above views is fully convincing and that a third approach should be applied instead (Von Bogdandy and Schill, 2011). Accordingly, the appropriate way to settle this dispute is to apply the principle of sincere cooperation ${ }^{65}$. The $\mathrm{CJ}$ and national constitutional courts must fully and loyally cooperate in determining whether a particular value, promoted by a Member State, is covered by its national identity. During that cooperation, it is for the Member State to decide on the 'content' of its national identity, while the $\mathrm{CJ}$ is only empowered to determine the relevance of national identity under EU law (Von Bogdandy and Schill, 2011). The CJ cannot, however, replace the assessment carried out by the Member State with its own examination.

The justification for this solution can have pragmatic grounds also. EU institutions do not have the duty to know all of the Member States' constitutional systems, especially issues which individual States themselves regard to be crucial enough for them to be covered by the notion of their national identities. The EU, including the CJ, is not competent to decide what is covered by the national identity of each Member State (Von Bogdandy and Schill, 2011) - especially since the constitutional law of a given State Can reflect its historical, cultural, religious and other kinds of heritage which differentiates States from each other. Indeed, even if multiple States had similar historical

\footnotetext{
62 Decision C (2004) 3060, para. 261-262.

63 Judgment BVerfGE.

64 Judgment K 32/09.

65 Article 4(3) TEU.
} 
experiences, their attitude towards them would not necessarily be analogues - different States can demonstrate different sensibilities towards similar values.

It must thus be left to the Member State concerned to submit a claim when to deem its national identity to be endangered. One may even say that if a Member State does not raise a claim that a particular value is so important to that country that it must be protected by the national identity principle, then such value is not in fact of such an importance for that State, or is not in fact at all endangered. Otherwise, the State would have invoked the need the national identity principle. The Member State does not, however, have to raise such a claim at a specific time in the procedure - it retains this right within the judicial proceedings held before EU courts even if it has not raised such a claim in the earlier administrative proceedings before the EC. Should such claim be raised, an EU institution (be it the EC during administrative proceedings, or EU courts in its judicial proceedings) has the legal duty to examine it thoroughly before deciding the case.

It is for the Member State to decide what values it seeks to protect, while the $\mathrm{CJ}$ is the institution empowered to adjudicate if in the case at hand a particular value is protected by the national identity principle. However, the finding that it is for the Member State concerned, rather than for EU institutions, to decide what values are covered by a given State's national identity, does not provide an answer to the question whether it has any significance who in that State decided that such value is covered by national identity or who represents that State before the CJ. Current CJ jurisprudence suggests that this answer is, in fact, important since the scope and intensity of the examination exercised by the $\mathrm{CJ}$ can vary depending on if, in the case at hand, it received an opinion from a national constitutional or supreme court. 'The ECJ may be a more active censor than national constitutional courts, but Sayn-Wittgenstein (and Omega) suggests that it is more indulgent and tolerant if the national constitutional court has pronounced on the matter. In the cases mentioned above where an appeal to national constitutional identity was rejected, no national constitutional court had clarified the national status and meaning of the constitutional norm or principle.' (Besselink, 2012).

The above quote refers to the CJ jurisprudence on national identity. Importantly, another conclusion can be drawn from that jurisprudence other than that the intensity of the CJ's examination depends on the involvement of national constitutional or supreme courts. Of relevance is also the very nature of the disputes where claims concerning national identity were in fact successful, especially where the examined cases had an economic character. 
Hence, for example, the abovementioned Sayn-Wittgenstein and Omega ${ }^{66}$ concerned free movement of persons and the freedom to provide services respectively. Therein, even though their areas touched upon the very foundations of the EU legal system, the examined disputes did not have an economic character (Sayn-Wittgenstein) or their economic character was found to be marginal (Omega). In those cases, the CJ carried out hardly any examination concerning the proportionality of the national measures (Sayn-Wittgenstein) or its examination was very light (Omega). This line can also be found in Runevič-Vardyn where the CJ linked national identity with the protection of a State's official national language ${ }^{67}$ and in Las $^{68}$ where it stated that the EU must respect the national identity of its Member States, which includes the protection of its official language or languages. The aforementioned cases did not have an economic character.

By contrast, the Michaniki case had a strong economic character. Although the CJ did not directly refer to national identity (the examination of which was the core of the opinion of the AG), it nevertheless followed the opinion of the AG and carried out an extensive examination of the proportionality of the national measures at hand. Ultimately, the CJ found them to be disproportional. Also in Commission v. Luxemburg, which concerned the freedom of establishment, the $\mathrm{CJ}$ rejected arguments concerning the need to use the national language, and decided that the contested national measures were disproportionate ${ }^{69}$. In O'Brien, the $\mathrm{CJ}$ failed to find any link connecting the case to national identity ${ }^{70}$ stating that applying EU law to the national judiciary which, according to national rules, plays an essential role in the national constitutional order of a Member State, does not automatically mean that its national identity has been breached.

Although neither of the above findings were made in State aid cases, they nonetheless can provide some indications as to what to expect from EU courts should they be tasked with conducting an examination of the compatibility of a recovery order against a Member State's national identity. State aid cases have a strong economic character and, by definition, may have an impact on the Internal Market. According to the CJ, a recovery order is the logical consequence of finding that a given aid is unlawful, and it is granted for the purpose of re-establishing pre-existing market conditions. A recovery order is a form of public intervention meant to improve the legal situation of

${ }^{66}$ In this case, the CJ did not directly refer to national identity but still referred to the national constitution.

67 C-391/09 Runevič-Vardyn, para. 86.

68 C-202/11 Las, para. 26.

69 C-51/08 Commission v. Luxemburg, para. 124.

70 C-393/10 O’Brien, para. 49. 
entrepreneurs whose competitor was granted unlawful aid. Deciding not to recover such incompatible aid would result in maintaining the distortion on the Internal Market. Hence, the examination concerning the compatibility of the recovery order with the principle of national identity is to include a detailed examination of proportionality. As the EU interest in restoring pre-existing market conditions by recovering the unlawful aid must normally take precedence over the interests of the beneficiary (as well as that of the Member State) in avoiding the enforcement of the repayment duty ${ }^{71}$, the proportionality test in State aid cases is to be rather strict.

That test does not, however, refer to the examination of compatibility of a recovery order with the principle of proportionality (general principle of EU law) as, according to EU courts, recovery of unlawful aid is the logical consequence of finding the aid to be unlawful. Recovery of such aid cannot in principle be regarded as disproportionate to the objectives of the Treaty. In applying the proportionality test in order to carry out the examination of a national identity claim against a recovery order, the EU institution (be it EU courts or the EC) should ${ }^{72}$ apply this test as a way of examining if refraining from recovering the aid would be proportional to the objectives of the Treaty; that is to say, not if recovery is proportional, but if refraining from it is. The obligation of the EU to respect the national identities of its Member States derives explicitly from Article 4(2) TEU, and therefore their national identity deserves protection. No Member State has to prove it. But that does not mean that in particular cases giving protection to certain values would be proportional to the objectives of the Treaty and so it must be tested.

\section{Conclusions}

The above observations suggest that, according to the current state of the CJ jurisprudence, it would be highly unlikely for EU courts to adjudge that the EC have breached the principle of national identity by ordering a Member State to recover unlawful State aid. This view gains support from the fact that the EU judiciary has yet to render even a single judgment ruling that the EC breached the national identity principle by ordering a Member State to recover unlawful aid. Moreover, the CJ has so far only acknowledged values which do not have an economic nature, or the economic character of which is lower than the value said to be covered by national identity. In cases where

71 T-198/01 R Technische Glaswerke Ilmenau GmbH, para. 114.

72 Since EU courts have not yet carried out such an examination in State aid cases, this is more of a de lege ferenda argument. 
the CJ rejected arguments based on the national identity principle, it carried out extensive examinations of the proportionality of limiting the scope of EU law against the national identity of a Member State.

On the other hand, the fact that EU courts have not yet referred to the national identity principle in State aid cases, and that they carry out extensive proportionality examinations in cases of an economic character, cannot serve as conclusive evidence that such a verdict is not to be made. Unlikely does not mean impossible.

It must be stressed first of all that the national identity clause is not limited (formally) to particular legal areas, and it is for Member States to decide what values are covered by the scope of their national identity. Furthermore, even though the $\mathrm{CJ}$ has delivered seven judgments referring to the national identity principle so far, this can still be seen as only the beginning of this jurisprudential line with more rulings to be expected. Although the CJ carries out stricter proportionality tests in cases of an economic nature (which would also cover State aid) than in those of a non-economic character, the intensity of such examinations is yet to be established.

Lastly, even State aid cases can vary among themselves and it is not unlikely that by ordering a recovery of an aid the EC would endanger higher values, which ought to be protected under national constitutions. Those values could possibly be of such a status that their protection could be seen as necessary in order to protect the national identity of a Member State. It is worth mentioning that the cases adjudged so far, where the CJ rejected arguments based on national identity, have not been supported by views and opinions made by national supreme or constitutional courts. One may not deny the view expressed by Besselink that the participation in a European case of national supreme or constitutional courts can influence the intensity of the examination carried out by the CJ.

It is thus fair to say that it is not impossible, albeit it would be an extremely rare case, to successfully invoke the national identity principle in State aid cases in order to evade the recovery of unlawful aid. One purely theoretical example (although it may be seen differently by EU courts) may concern the situation of public television benefiting from public funding. The rules and limits according to which public television can be publicly financed are contained in the Communication from the Commission on the application of State aid rules to public service broadcasting ${ }^{73}$. Should those rules and limits be exceeded, the financing provided to such a broadcaster could be found to be unlawful State aid subject to recovery. It is not impossible, however, to imagine a situation where in a particular situation the recovery of such an

${ }^{73}$ OJ C 257, 27.10.2009, p. 1. 
aid could affect the national identity of a Member State, as the main task of such a broadcaster would be, for example, the promotion of a Member State's culture, history and keeping community bonds between citizens dispersed throughout the world. In such a situation, even though the financing provided to public television would be considered aid, and what's more, aid incompatible with the Internal Market, issuing a recovery order could be contrary with that Member State's national identity.

\section{References}

Besselink, L.F.M. (2012). Respecting Constitutional Identity in the EU, Case Note to Case C-208/09, Sayn-Wittgenstein v. Landeshauptmann von Wien, Judgment of the Court (Second Chamber) of 22 December 2010, nyr. Common Market Law Review, 49(2), 671-693.

Brandtner, B. (2013). Recovery and Insolvency - A case for greater flexibility? GCLC Lunch Talk. Retrived from: https//www.coleurope.eu.

Cieśliński, A. (2003). Wspólnotowe prawo gospodarcze. Warszawa: Wydawnictwo C.H. Beck.

Cloots, E. (2015). National Identity in EU Law. Oxford: Oxford University Press, http:// dx.doi.org/10.1093/acprof:oso/9780198733768.001.0001.

Fontanelli, F. (2011). The European Union's Charter of Fundamental Rights two years later. Perspectives on Federalism, 3(3).

Giraud, A. (2008). A study of the notion of legitimate expectations in State aid recovery proceedings: „Abandon all hope, ye who enter here”? Common Market Law Review, 45(5), 1399-1431.

Jaros, K., Ritter, N. (2004). Pleading Legitimate Expectations in the Procedure for the Recovery of State Aid - What are the Recent Developments in Case Law and the Commission's Practice? European State Aid Law, 4.

Łętowska, E. (2008a). Dialog i metody. Interpretacja w multicentrycznym systemie prawa (cz. I). Europejski Przeglad Sąowy, 11.

Łętowska, E. (2008b), Dialog i metody. Interpretacja w multicentrycznym systemie prawa (cz. II), Europejski Przegląd Sądowy, 12.

Mik, C. (2000). Europejskie prawo wspólnotowe. Zagadnienia teorii i praktyki. T. 1. Warszawa: Wydawnictwo C. H. Beck.

Sinnaeve, A. (2010), Procedure Regarding Unlawful Aid. In: Heidenhain, M. (ed.). European State Aid Law. München: Verlag C.H. Beck.

Thym, D. (2009). In the name of Sovereign Statehood: a critical introduction to the Lisbon judgement of the German Constitutional Court. Common Market Law Review, 46(6), 1795-1822.

Tridimas, T. (2006). General Principles of EU Law, Oxford: Oxford University Press.

Von Bogdandy, A. and Schill, S. (2011). Overcoming absolute primacy: respect for National identity under the Lisbon Treaty, Common Market Law Review, 48(1), 1-38. 